\title{
Experimental model for the study of chronic renal ischemia in rats. Morphologic, histological and ultra-structural analysis ${ }^{1}$
}

\author{
Modelo experimental para o estudo da isquemia renal crônica em ratos. Análises \\ morfológica, histológica e ultra-estrutural
}

\author{
Clóvis Luís Konopka², Alexandre Jurach ${ }^{3}$, Orlando Carlos Belmonte Wender $^{4}$ \\ 1. Work performed at Experimental Laboratory, Department of Biochemistry, Federal University of Santa Maria (UFSM). Rio Grande do \\ Sul, Brazil. \\ 2. Assistant Professor, Vascular Surgery, Department of Surgery, UFSM. Rio Grande do Sul, Brazil. \\ 3. Master, Vascular surgeon, UFSM. Brazil. \\ 4. Associate Professor, Cardiovascular Surgery, Department of Surgery, Federal University Rio Grande do Sul (UFRGS). Brazil.
}

\begin{abstract}
Purpose: To evaluate a model of chronic renal ischemia in rats and to characterize the effects on renal tissue. Methods: 168 Wistar rats were divided into two equal groups, control (GC) and ischemia (GI). The animals of the GI ( $\mathrm{n}=84$ ) were submitted to partial ligation of the left renal artery, and the animals of GC $(n=84)$ stayed with the renal artery intact. In seven successive and identical periods of time, in weekly intervals, 12 animals of each group were submitted to nephrectomy, with morphometric determinations and histological and ultra-structural analysis. Results: The GI presented progressive reduction in renal weight, volume and cortical thickness observed from the $7^{\text {th }}$ day of the experiment, reaching maximum degree in the $49^{\text {th }}$ day $(\mathrm{p}<0.05)$. The proximal tubular atrophy in the GI was observed in $75 / 84$ analysis $(89,2 \%)$, with highly significant difference among the groups starting from the $7^{\text {th }}$ day $(p=0.0009)$ and in the other periods of the experiment $(p=0$ $.00001)$. The most prevalent interstitial alteration was the infiltrate, present in $98,8 \%$ of the GI, with highly significant difference among the groups in the whole experiment $(\mathrm{p}=0.00001)$. Ultra-structural analysis didn't demonstrate glomerular lesions, evidencing that the glomerule preserves its intact architecture during chronic ischemia. Conclusion: The model showed that chronic renal ischemia in rats provokes progressive renal atrophy, with preservation of glomerular structure. Key words: Kidney. Ischemia. Models, Animal. Rats.
\end{abstract}

\section{RESUMO}

Objetivo: Avaliar um modelo de isquemia renal crônica em ratos e caracterizar os efeitos no tecido renal. Métodos: Utilizaramse 168 ratos Wistar divididos em dois grupos iguais, controle (GC) e isquemia (GI). Os animais do GI ( $\mathrm{n}=84$ ) foram submetidos à ligadura parcial da artéria renal esquerda, e os animais do $\mathrm{GC}(\mathrm{n}=84)$ permaneceram com a artéria renal intacta. Em sete períodos de tempo sucessivos e iguais, em intervalos semanais, 12 animais de cada grupo foram submetidos à nefrectomia, com determinações morfométricas e análises histológica e ultra-estrutural. Resultados: O GI apresentou redução progressiva no peso, volume e espessura cortical renal a partir do $7^{\circ}$ dia do experimento, atingindo grau máximo no $49^{\circ}$ dia $(\mathrm{p}<0.05)$. A atrofia tubular proximal no GI ocorreu em $75 / 84$ análises $(89,2 \%)$, com diferença altamente significativa entre os dois grupos a partir do $7^{\circ} \mathrm{dia}(\mathrm{p}=0.0009)$ e nos demais períodos do experimento $(\mathrm{p}=0.00001)$. A alteração intersticial mais comum no GI foi o infiltrado, presente em $98,8 \%$, com diferença altamente significativa entre os dois grupos ( $\mathrm{p}=0.00001)$. A análise ultra-estrutural não demonstrou lesões glomerulares, evidenciando que os glomérulos preservam sua arquitetura intacta durante a isquemia crônica. Conclusão: O modelo mostrou que a isquemia renal crônica em ratos provoca atrofia renal progressiva, com preservação da estrutura glomerular.

Descritores: Rim. Isquemia. Modelos Animais. Ratos.

\section{Introduction}

Occlusive disease of the renal arteries or renovascular disease (RVD) can produce two different and independent clinical conditions: renovascular hypertension (HRV) and renal insufficiency (RI). HRV was described initially in 1934 from the pioneering experimental works performed by Goldblatt et al. ${ }^{1}$ Traditionally the study of RVD has been centered in the physiopathology and management of the resulting renovascular hypertension, due to great clinical interest in the cure of secondary hypertension. ${ }^{2}$ Minor attention has been directed for the functional repercussions of chronic ischemia contributing to progressive loss of renal function and consequent requirement for dialysis. These observations brought about Jacobson, in 1988, to create the term ischemic nephropathy (IN). ${ }^{3}$ The development of IN is conditioned to chronic evolution of global renal 
ischemia with emergence of atrophy and loss of structural integrity. Clinically take place progressive elevations in creatinine levels and reduction in renal dimensions. Mailloux et $\mathrm{al}^{4}$ reported that the largest mortality in patients on dialysis program happens exactly among the bearers of IN, in comparison with other causes of end stage renal disease. The prolonged occlusion of the renal arteries for induction of chronic ischemia has been used in experimental models of RVH. Most of these studies have been approaching the physiopathology of the hemodynamic alterations in glomerular level, without considering the morphologic and ultra-structural alterations induced by ischemia on the tubulo-interstitial compartment. However, clinicopathologic studies have been demonstrating that the interstitial (fibrosis) and tubular (atrophy) alterations are correlated in a better way with the renal function than the glomerular lesions itself. Advanced glomerular lesions can be accompanied by normal renal function. ${ }^{3}$ The concepts developed with the study of acute renal ischemia have limited applicability in the chronic compromising. The progressive atrophy of tissues and organs submitted to chronic ischemia is the result of adaptive alterations, seeking to the realignment among the offer and demand of oxygen. However, the limits of this process - up to how much the atrophy is beneficial and protectoral and more important, when it is irreversible - are not fully established. In this context, several important related questions remain yet without answer: (1) After what reduction in renal blood flow took place alterations in renal function? (2) Ischemic nephropathy is simply the death of renal cells due to lack of oxygen and nutrients, or there are more complex renal mechanisms of cellular lesion, adaptation and possible repair? (3) There are histological markers that regulate the reversibility of the picture with renal revascularization? The objective of our study is to evaluate an experimental model in rats of chronic renal ischemia of the type Goldblatt two kidneysone stenosis and to characterize the morphologic, histological and ultra-structural alterations present in this model.

\section{Methods}

The experiment was approved by the Committee of Ethics in Research of the Federal University of Rio Grande do Sul -UFRGS and Federal University of Santa Maria UFSM. Were utilized 168 females Wistar rats (Rattus norvegicus albinus), with age among 60-75 days and minimum weight of 150 grams.

- GI: Ischemia Group: $(n=84)$ : rats with ischemia on the left kidney, divided into seven subgroups with 12 animals each.

- GC: Control Group: $(n=84)$ : rats without ischemia on the left kidney, divided into seven subgroups with 12 animals each.

The experiment was divided into seven successive and identical periods of time, corresponding to weekly intervals: Time 0: beginning of the experiment; Time 1: seven days after the beginning, and so forth, with Time 7: 49 days after and final of the experiment. Each animal was submitted to two surgical procedures, the first in the time zero and the second at the end of one of the times, in agreement with the group to which the animal belonged. To each subgroup of 12 animals corresponded a period of time.

\section{First procedure}

In the time 0 , marking the beginning of the experiment, the 84 rats of GI and the 84 rats of GC were submitted to the first procedure. After intraperitoneal anesthesia with sodic tiopental (Thionembutal $\AA$, Abbott Laboratories of Brazil Ltd.) in the dose of $20 \mathrm{mg} / \mathrm{kg}$, was performed a midline abdominal incision. Next, with surgical magnifying glasses $(6,3 \mathrm{X})$, was carried out the microsurgical dissection with isolation of the left renal artery. The confirmation of the presence of only one renal trunk without accessory arteries was verified through gentle clamping of the artery with direct observation of the kidney coloration. In the presence of more than one renal artery the animal was discarded and substituted for other. At this stage in the animals belonging to GI was produced one stenosis in the left renal artery through the placement of one atraumatic ligation with surgical thread of 5-0 nonabsorbable polipropilene suture (Prolene $\AA$, Ethicon - USA) around a cylindrical probe with $0,26 \mathrm{~mm}$ diameter, corresponding to the metallic portion of a $30 \mathrm{G}$ needle, to allow a slack constriction of the artery with partial obstruction of the lumen. This procedure allowed the reduction in about $80 \%$ of the initial diameter of the artery, producing one hemodynamically significant stenosis. At the end of this procedure, in order to assure that the ligation had just produced stenosis without occlusion of the artery, the renal perfusion was certified through three maneuvers: $1^{\text {st }}$ - presence of capillary filling on the renal surface; $2^{\text {nd }}-$ presence of flow in the renal artery distally to the ligation and $3^{\text {rd }}$ - the direction of blood flow in the renal vein, which should be originating from the kidney towards the inferior vena cava. The production of a stenosis in the left renal artery resulted in a model similar to Goldblatt two kidneys-one clip. ${ }^{1}$ In the animals of GC the renal artery was just dissected, without producing a stenosis. Before closure the abdominal incision, we proceeded to intraperitoneal administration of prophylactic antibiotic (Cloranfenicol Quemicetina ${ }^{\circledR}$, Carlo Erba) in the dose of $25 \mathrm{mg} / \mathrm{ml}$. During the surgical procedure there was no replacement of fluids and electrolytes. After the anesthetic recovery the animals were transferred to the sectorial vivarium and maintained in plastic cages covered with wire screen, measuring $50 \mathrm{x} 40 \mathrm{x}$ $40 \mathrm{~cm}$ (depth $\mathrm{x}$ width $\mathrm{x}$ height), with at most six animals for cage. During the whole experiment the animals had free

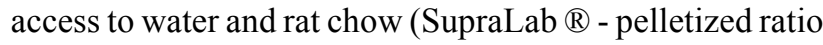
for laboratory animals, Supra Industry of Foods Ltd.). The room temperature was controlled between $20-24{ }^{\circ} \mathrm{C}$, with relative humidity of the air between $40-70 \%$. The daily cycle of the rodents were respected with 12 hours/day having light and 12 hours/night not having light.

\section{Second procedure}

At the completion of each period of seven days and so forth (times one to seven), 12 animals of each group were 
submitted to the second laparotomy, with exeresis of the left kidney. Next it was determined the renal weight ( $\mathrm{mg}$ ) and bipolar, transverse and anteroposterior renal diameters $(\mathrm{mm})$, for calculation the renal volume $\left(\mathrm{mm}^{3}\right){ }^{5}$ This was calculated through the formula $\mathrm{V}=0,523 \times \mathrm{BPD} \times \mathrm{TD} \times \mathrm{APD}$, where 0,523 : correction coefficient, given the ellipsoid format of the kidney with the flat poles; BPD: bipolar diameter in mm; TD: transverse diameter in mm; APD: anteroposterior diameter in $\mathrm{mm}$. After sagital opening of the kidney into the midline in two equal halves, the cortical thickness (mm) was verified.

\section{Histopathologic exam}

The kidneys were next fixed during 12 hours in alcoholic solution of Bouin (ethyl alcohol $80 \%$, formalin $40 \%$ and picric acid), and stored in refrigerator at $4{ }^{\circ} \mathrm{C}$. The specimens obtained were then transferred for a solution of ethyl alcohol $50 \%$ in water, and sent for processing in the Service of Pathology of the Department of Human Pathology (UFSM) for histological analysis under optical microscopy always for the same pathologist, without the previous knowledge of the group of each rat $^{6}$. For the histological analysis was utilized a semiquantitative score developed by the authors:

- Glomerules: ten units analyzed.

- Collapse: absent / partial / total.

- Glomerular hypertrophy: absent / present.

- Glomerulosclerosis: absent / slight / moderate / moderate - intense / intense.

- Sclerosis index: no lesion / lesion of up to $25 \%$ of the glomerule / lesion between $25-50 \%$ / lesion between 50 $75 \%$ / sclerosis between $75-100 \%$ of the glomerule.

- Distribution of glomerulosclerosis: absent / diffuse widespread in the cortex / superficial focal, located in the outer half of the cortex / focal juxtamedullar, located in the inner half of the cortex.

\section{- $\underline{\text { Proximal tubules: }}$}

- Tubular atrophy: absent / slight / moderate / intense.

- Distribution of tubular atrophy: absent / diffuse widespread in the cortex / superficial focal, located in the outer half of the cortex / focal juxtamedullar, located in the inner half of the cortex.

\section{- Interstitial:}

- Interstitial infiltrate: absent / slight / moderate / moderate - intense / intense.

- Distribution of the infiltrate: absent / diffuse widespread in the cortex / superficial focal, located in the outer half of the cortex / focal juxtamedullar, located in the inner half of the cortex.

- $\underline{\text { Arterioles: }}$ five units split up transversely.

- Arteriolosclerosis: absent / slight / moderate / intense.

\section{Ultra-structural exam}

For the acquisition of the specimens for ultra-structural analysis with electronic microscopy, one animal of each subgroup (totaling 14 animals) was submitted to terminal fixation with selective perfusion of the left kidney with maximum perfusion pressure of $120 \mathrm{mmHg}$. Initially was used cold heparinized saline solution during three minutes, following for cold tamponated solution of paraformaldehyde $2 \%+$ glutaraldehyde $2,5 \%$ during four minutes. At the end of the perfusion, the left kidney was withdrawn, and with an ultrafine sheet of steel (Gillette ${ }^{\circledR}$, Gillette of Brazil Ltd.), using the protection of a wax plate, were obtained three cubic blocks of renal cortex with one cubic millimeter each. These blocks were put immediately into one recipient containing the cold perfusion solution and stored in refrigerator at $4{ }^{\circ} \mathrm{C}$ for six hours. After this period the material was directed to the Service of Electronic Microscopy of UFSM for processing. In the ultra-structural analysis were considered the presence or absence of findings, as follows:

- Proximal tubular cells with undifferentiated appearance:

- Cellular membrane with decrease/absence of the lateral basal invaginations (brush border).

- Organelles with undifferentiated appearance and reduced in number.

- Loss of the cellular polarization.

- Tubulitis (mononuclear cells infiltrate):

- Tubular cells in contact with mononuclear cells presenting occasional degenerative alterations, like focal destruction of cellular membrane and rupture of organelles.

- Proximal tubular cells with duplication of the basal membrane.

- Electron-dense deposits.

- Increase of electron-dense deposits in the cells of the juxtaglomerular apparatus.

- Cellular debris in the tubular lumen.

\section{Statistical analysis of data}

The means, medians, standard-deviations and maximum and minimum variations (descriptive statistics) were computed for discrete variables (example: renal weigh). The frequencies and relative frequencies were determined for categorical variables (example: histological analysis score). The normal distribution of discrete variables was tested by the Kolmogorov-Smirnov test. The control and ischemia groups were compared by Mann-Whitney test for variables with non-normal distribution, and by Student $t$ test for variables with normal distribution. To test the effect of time variation inside each group was performed the variance analysis (ANOVA) for variables with normal distribution, and Kruskal-Wallis test for variables with nonnormal distribution. In all tests the results were considered significant at a significance level of $5 \%(\mathrm{p}<0,05)$. 


\section{Results}

Weigh, volume and cortical thickness

There were no deaths of animals along the experiment. The observed results for weight, volume and renal cortical thickness in both groups are expressed in Table 1. There was statistically significant difference in weight and cortical thickness too early, from the $7^{\text {th }}$ day (time 1 ) of the experiment, while the significant difference in renal volume was observed after the $14^{\text {th }}$ day (time 2). Only at the end of the experiment $\left(49^{\circ}\right.$ day) was observed significant difference between all the three parameters $(\mathrm{p}<0.05)$, when compared with the GC. In this period also were registered the smallest medium values for weight, volume and renal cortical thickness in the animals of GI.

TABLE 1 - Comparison between control and isquemia groups for renal weight, volume and cortical thickness at different times of the experiment.

\begin{tabular}{|c|c|c|c|c|c|c|}
\hline \multirow[b]{2}{*}{ Time* } & \multicolumn{3}{|c|}{$\begin{array}{l}\text { Control Group } \\
(\mathrm{n}=84)\end{array}$} & \multicolumn{3}{|c|}{$\begin{array}{c}\text { Ischemia Group } \\
(\mathrm{n}=84)\end{array}$} \\
\hline & Weight $^{1}$ & Volume $^{2}$ & $\begin{array}{c}\text { Cortical } \\
\text { Thickness }^{3} \\
\end{array}$ & Weight & Volume & $\begin{array}{c}\text { Cortical } \\
\text { Thickness } \\
\end{array}$ \\
\hline 1 & 667,9 & 542,8 & 2,12 & 645,7 & 458,9 & 1,69 \\
\hline 2 & 679,3 & 555,8 & 2,06 & 584,2 & 401,7 & 1,75 \\
\hline 3 & 795,5 & 619,5 & 2,36 & 580,4 & 433,2 & 1,96 \\
\hline 4 & 832,2 & 635,1 & 2,12 & 487,8 & 366,6 & 1,83 \\
\hline 5 & 693,4 & 502,8 & 2,21 & 554,7 & 405,9 & 1,87 \\
\hline 6 & 803,4 & 606,7 & 2,51 & 669,7 & 496,2 & 2,08 \\
\hline 7 & 892,1 & 695,2 & 2,42 & 382,2 & 270,6 & 1,52 \\
\hline Mean & 766,2 & 593,9 & 2,26 & 557,8 & 404,7 & 1,81 \\
\hline SD & 86,57 & 64,72 & $\mathbf{0 , 1 7}$ & 97,64 & 72,54 & 0,18 \\
\hline
\end{tabular}

Weight: $\mathrm{mg}$; Volume: $\mathrm{mm}^{3}$; Cortical thickness: $\mathrm{mm}$

*Each time corresponds a period of 7 days and in each period 12 animals were analyzed $(n=12)$.

${ }^{1}$ Statistically significant differences in the weight among the groups in the times $1,3,4$ and 7 (p $<0.05$ ).

2 Statistically significant differences in the volume among the groups in the times $2,3,4$ and 7 ( $p \leq 0.05$ ).

${ }^{3}$ Statistically significant differences in the cortical thickness among the groups in the times $1,2,6$ and 7 (p $<0.05$ ).

\section{Histological analysis (Figures 1-5)}

Histological alterations were not observed in the animals of GC along the whole experiment. The semiquantitative alterations observed in the glomerules, proximal tubules, interstice and arterioles of the GI are registered in the Table 2. In this group, the most frequent alterations were the interstitial infiltrate, present in $98,8 \%$ $(83 / 84)$ of the studied animals and the proximal tubular atrophy, observed in $89,3 \%(75 / 84)$ of the analysis. The glomerular collapse was present in $23,8 \%(20 / 84)$, and the sclerosis (glomerulosclerosis) in only two animals $(2,4 \%)$. The arteriolosclerosis was found lonely in one case $(1,2 \%)$. The interstitial infiltrate occurred in a precocious way since the $1^{\text {st }}$ time ( 7 days) in almost the totality of animals (except one animal at the time 6), with this occurrence highly significant along all times of the experiment $(p=0.00001)$ (Table 3$)$. There was predominance of slight and moderate infiltrate $(40,5 \%$ and $39,3 \%$ respectively), with significant difference at the times 2 and 3 (p. 0.05) and no significant difference at the other times $(p>0.05)$. The proximal tubular atrophy occurred predominantly in moderate degree $(42,9 \%)$, and there was not significant difference among the times of the experiment $(\mathrm{p}>0.05)$, according to Table 4 .

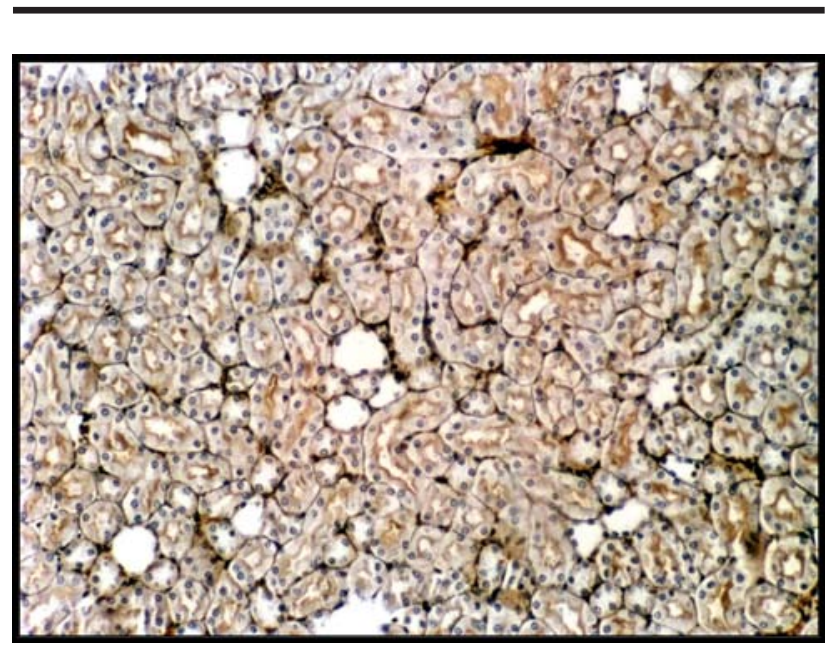

FIGURE 1 - Normal renal interstice and tubules in animal of GC at the time 3 (21 days). PASM, 100X. 


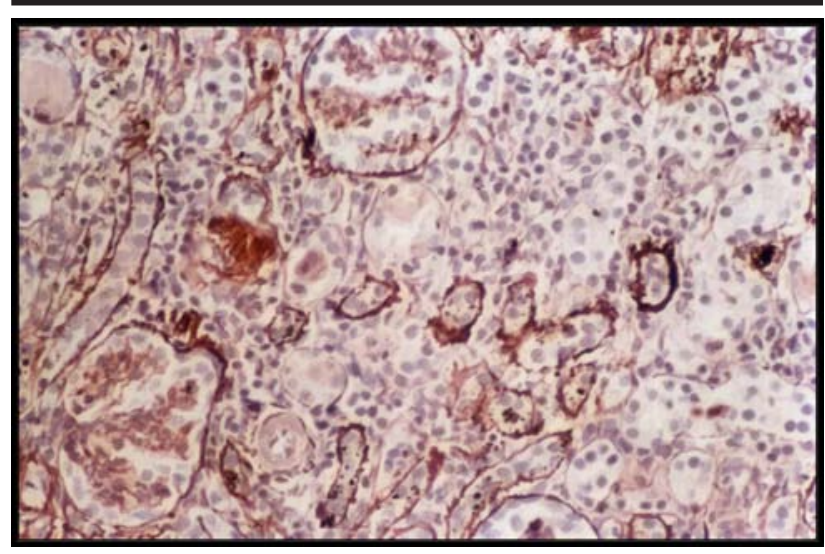

FIGURE 2 - Moderate tubular atrophy and interstitial infiltrate. Collapsed glomerules. Kidney from GI at the time 4 (28 days). PASM, $200 \mathrm{X}$.

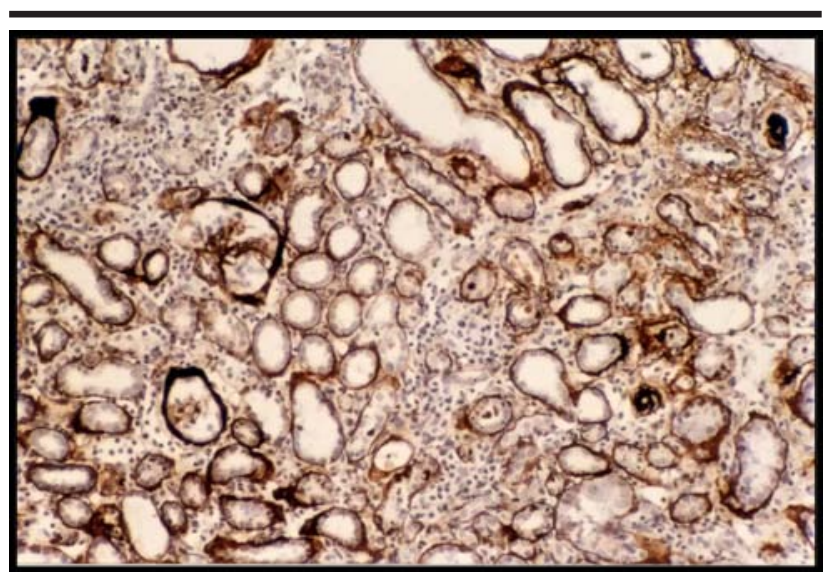

FIGURE 3 - Tubular atrophy and intense interstitial infiltrate. Kidney from GI at the time 3 (21 days). PASM, $100 \mathrm{X}$.

TABLE 2 - Results of the histological findings for glomerular, proximal tubular and interstitial alterations in the ischemia group $(n=84)$.

\begin{tabular}{cccccc}
\hline & \multicolumn{2}{c}{ Ischemia Group (n= 84) } \\
\hline & Arterioles & \multicolumn{2}{c}{ Glomeruli } & Prox Tub & Interstice \\
\hline Time $^{*}$ & Sclerosis & Collapse $^{\mathbf{1}}$ & Sclerosis $^{\mathbf{2}}$ & Atrophy $^{\mathbf{3}}$ & Infiltrate $^{4}$ \\
\hline 1 & 1 & 5 & 0 & 8 & 12 \\
\hline 2 & 0 & 0 & 1 & 12 & 12 \\
\hline 3 & 0 & 2 & 0 & 12 & 12 \\
\hline 4 & 0 & 3 & 0 & 11 & 12 \\
\hline 5 & 0 & 3 & 0 & 11 & 11 \\
\hline 6 & 0 & 1 & 0 & 11 & 12 \\
\hline 7 & 0 & 6 & 1 & $\mathbf{7 5}(84)$ & $\mathbf{8 3}(84)$ \\
\hline Total & $\mathbf{1}(84)$ & $\mathbf{2 0}(84)$ & $\mathbf{2}(84)$ & $\mathbf{8 9 , 3}$ & $\mathbf{9 8 , 8}$ \\
\hline
\end{tabular}

* In each period of time 12 animals were analyzed. Prox Tub: proximal tubules.

${ }^{1}$ Statistically significant differences in the times 1 and $7(\mathrm{p} \leq 0.05)$ and non-significant in the other times $(p>0.05)$.

${ }^{2}$ No statistically significant differences $(p>0.05)$.

${ }^{3}$ Highly statistically significant differences in the times $1(p=0.0009), 3(p=0.0001), 2,4,5,6$ and 7 ( $\left.p=0.00001\right)$.

${ }^{4}$ Statistically significant differences in the times $1(\mathrm{p} \leq 0.05), 2,3,4,5,6$ and $7(\mathrm{p}=0.00001)$.

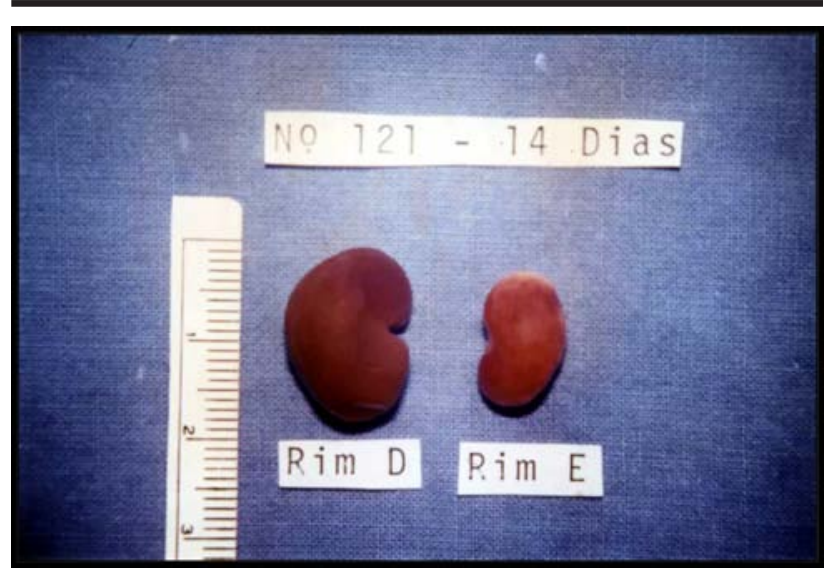

FIGURE 4 - Left and right kidneys from animal of GI at the time 2 (14 days). The reduction in the dimensions of the left kidney is observed.

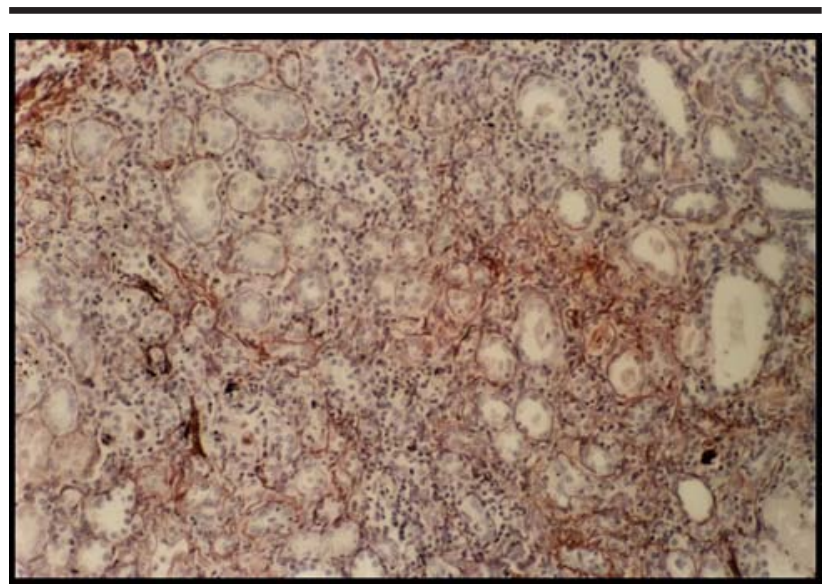

FIGURE 5 - Moderate tubular atrophy and intense interstitial infiltrate. Left kidney from GI at the time 3 (21 days). PASM, $100 \mathrm{X}$. 
TABLE 3 - Interstitial infiltrate score in the ischemia group $(n=84)$.

\begin{tabular}{ccccccc}
\hline \multicolumn{7}{c}{ Ischemia Group (n=84) } \\
\hline \multicolumn{7}{c}{ Interstitial Infiltrate ${ }^{\mathbf{1}}$} \\
\hline Time & Absent & Slight & Mod & M-Int & Intense & TOTAL \\
\hline 1 & 0 & 6 & 6 & 0 & 0 & 12 \\
\hline 2 & 0 & 8 & 3 & 1 & 0 & 12 \\
\hline 3 & 0 & 9 & 1 & 1 & 1 & 12 \\
\hline 4 & 0 & 3 & 8 & 1 & 0 & 12 \\
\hline 5 & 0 & 4 & 6 & 1 & 1 & 12 \\
\hline 6 & 1 & 2 & 6 & 3 & 0 & 12 \\
\hline 7 & 0 & 2 & 3 & 4 & 4 & 12 \\
\hline Total & $\mathbf{1}$ & $\mathbf{3 4}$ & $\mathbf{3 3}$ & $\mathbf{1 0}$ & $\mathbf{6}$ & $\mathbf{8 4}$ \\
$\mathbf{9}$ & $\mathbf{1 , 2}$ & $\mathbf{4 0 , 5}$ & $\mathbf{3 9 , 3}$ & $\mathbf{1 1 , 9}$ & $\mathbf{7 , 2}$ & $\mathbf{1 0 0}$ \\
\hline
\end{tabular}

${ }^{1}$ Statistically significant differences in the times 2 and $3(\mathrm{p} \leq 0.05)$ and no statistically significant differences in the other times $(\mathrm{p}>0.05)$. Mod: moderate; M-Int: moderate-intense.

TABLE 4 - Proximal tubules atrophy score in the ischemia group $(n=84)$.

\begin{tabular}{cccccc}
\hline \multicolumn{7}{c}{ Ischemia Group (n= 84) } \\
\hline \multicolumn{7}{c}{ Proximal tubules atrophy ${ }^{\mathbf{1}}$} \\
\hline Time & Absent & Slight & Mod & Intense & TOTAL \\
\hline 1 & 4 & 2 & 4 & 2 & 12 \\
\hline 2 & 0 & 7 & 4 & 1 & 12 \\
\hline 3 & 2 & 7 & 1 & 2 & 12 \\
\hline 4 & 0 & 3 & 7 & 2 & 12 \\
\hline 5 & 1 & 3 & 6 & 1 & 12 \\
\hline 6 & 1 & 1 & 9 & 5 & 12 \\
\hline 7 & 1 & 1 & 5 & $\mathbf{1 5}$ & $\mathbf{1 0 0}$ \\
\hline $\begin{array}{c}\text { Total } \\
\text { \% }\end{array}$ & $\mathbf{9}$ & $\mathbf{2 4}$ & $\mathbf{3 6}$ & $\mathbf{1 7 , 9}$ & \\
\hline
\end{tabular}

${ }^{1}$ No statistically significant differences between the times $(p>0.05)$.

Ultra-structural analysis (Figures 6-12)

The ultra-structural analysis with electronic microscopy demonstrated the presence of varied lesions only in cells of

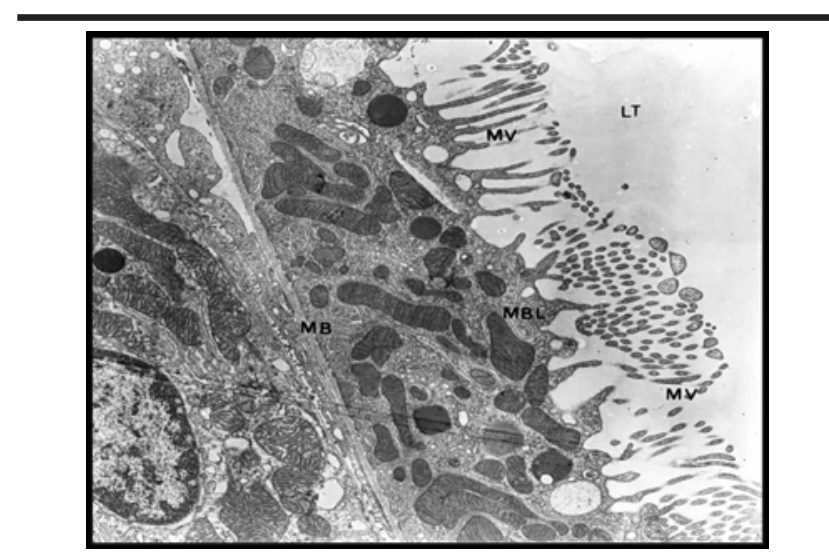

FIGURE 6 - Electronic photomicrography (12.000 X) from proximal tubular cell of the GI at the time 1 (7 days), demonstrating loss of cellular polarity with distortion and reduction in the quantity of intracellular organelles. Moderate reduction in number and height of microvilosities (board-in-brush). Cellular membrane with preserved baso-lateral invaginations. [LT: Tubular lumen, MV: Microvilosities, MB: Basal membrane, MBL: Basolateral membrane]. the proximal tubules, compatible with prolonged renal ischemia. Glomerular lesions were not observed, demonstrating that the glomerulus is preserved and with its intact architecture during the chronic ischemia (Chart 1).

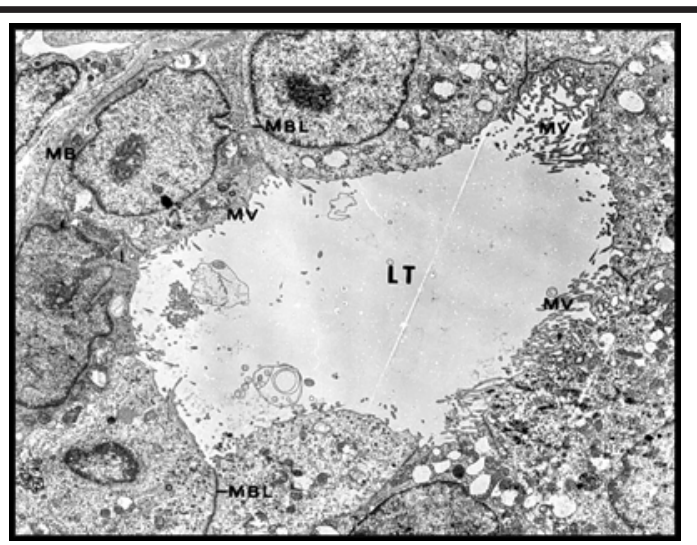

FIGURE 7 - Electronic photomicrography (4.725 X) of proximal tubule from the GI at the time 4 ( 28 days), demonstrating tubular cells with undifferentiated appearance associated with loss of cellular polarity. Mitochondrion and other intracellular organelles in reduced number. Simplification of basolateral membranes, amongst reduction of cellular height. The microvilosities of the brush border are markedly reduced. [LT: Tubular lumen, MV: Microvilosities, MB: Basal membrane, MBL: Basolateral membrane] 


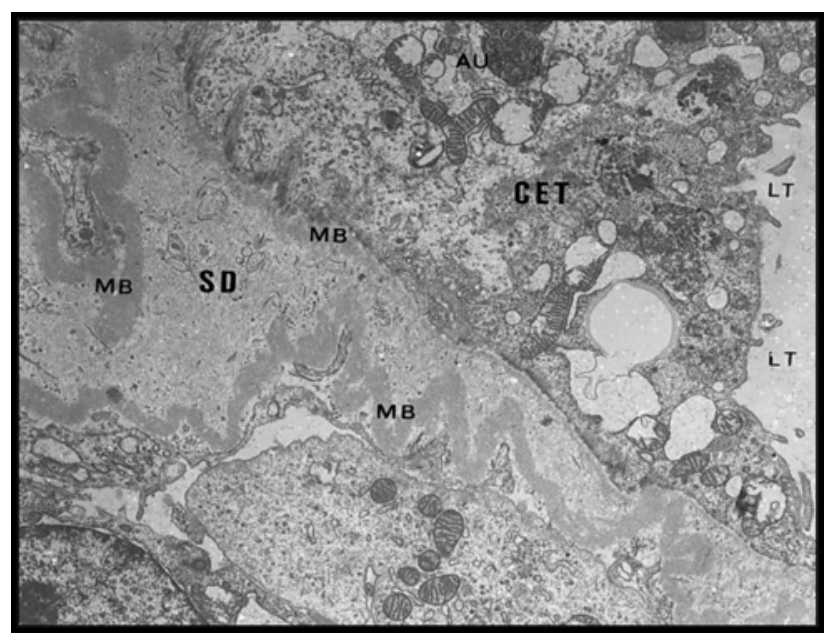

FIGURE 8 - Electronic photomicrography $(9.450 \mathrm{X})$ of proximal tubule from the GI at the time 4 (28 days). The basal membrane is duplicated and markedly tortuous, with moderately electrondense substance among the two layers. [CET: Tubular epithelial cell, AU: Autophagolysosome, MB: Basal membrane, LT: Tubular lumen. SD: Electron-dense substance].

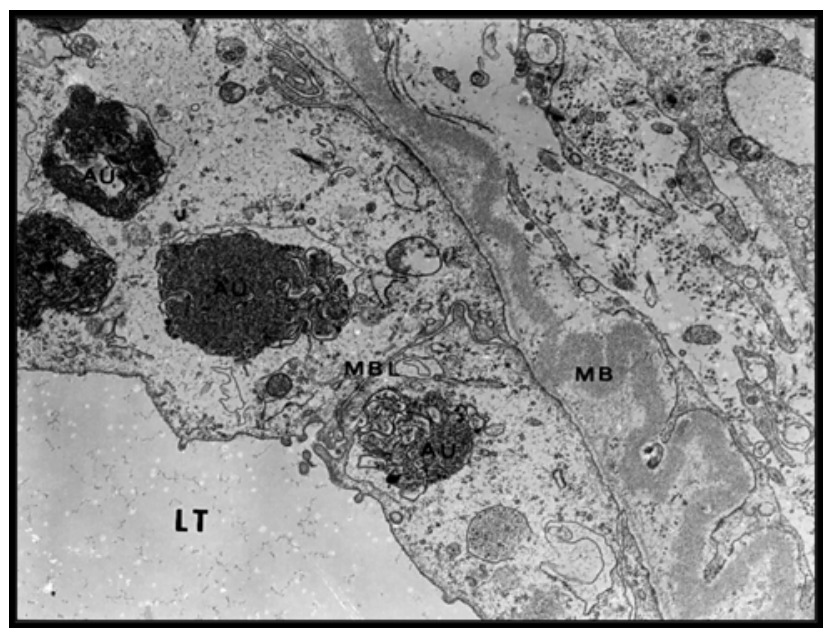

FIGURE 9 - Electronic photomicrography (15.000 X) of proximal tubule from the GI at the time 4 ( 28 days), demonstrating the presence of autophagolysosomes of debris from condensed necrotic tubular cells, reflecting the phenomenon of apoptosis. Total loss of cellular differentiation with complete atrophy of the board-in-brush, with elongated and tortuous basal membrane. Simplified basolateral membranes [LT: Tubular lumen, AU: Autophagolysosome, MB: Basal membrane, MBL: Basolateral membrane].

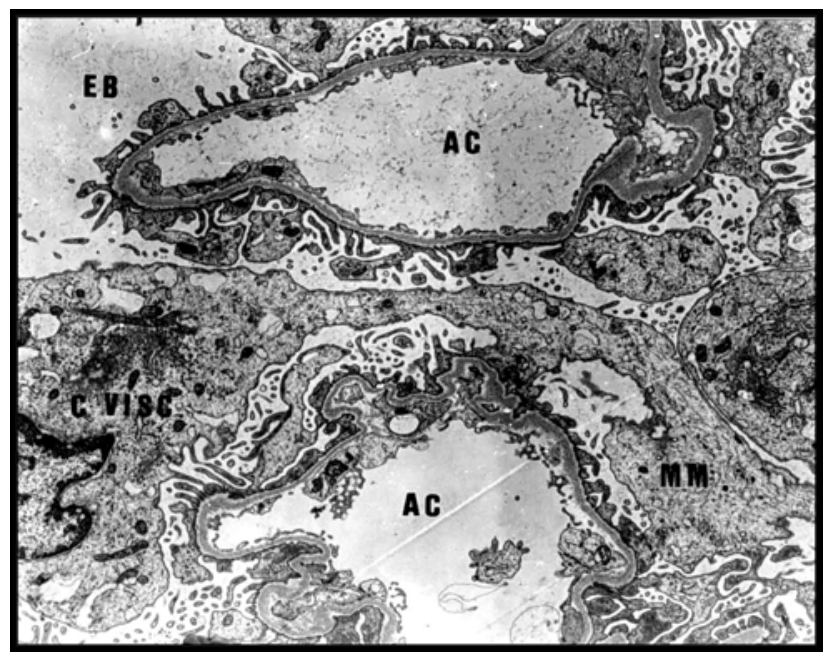

FIGURE 10 - Electronic photomicrography (7.500 X) of glomerulus from GI at the time 7 (49 days). The glomerulus is complete and with preserved architecture. [AC: Capillary loop, MM: Mesangial matrix, EB: Bowman's space, CVISC: Visceral epithelial cell].

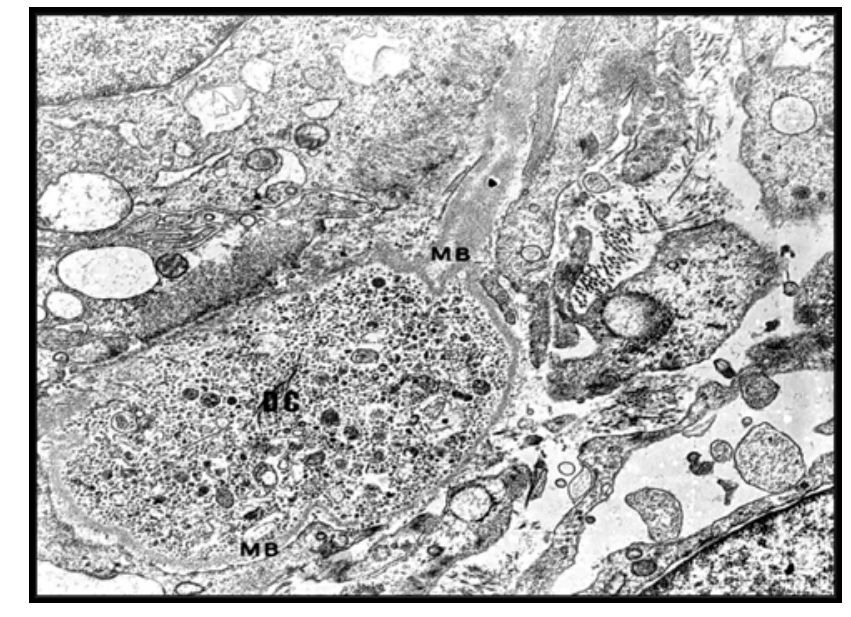

FIGURE 11 - Electronic photomicrography (15.000 X) of proximal epithelial tubular cell from GI at the time 4 (28 days), with the presence of cellular debris inside duplicated basal membrane, indicating possible repeated cycles of cellular necrosis / repair. [DC: Cellular debris, MB: Duplicated basal membrane]. 


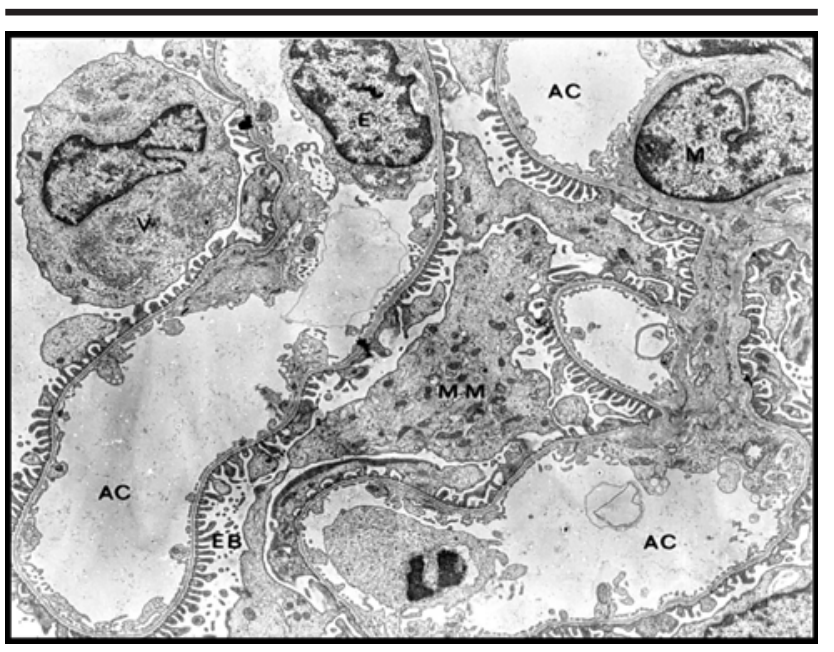

FIGURE 12 - Electronic photomicrography $(4.725 \mathrm{X})$ of renal glomerulus with normal appearance from animal of the GC at the time 7 (49 days). [V: visceral epithelial cell (podocyte), AC: Capillary loop, MM: Mesangial matrix, $\mathbf{E}$ : Endothelial cell, EB: Bowman's space, M: Mesangial cell].

\section{Discussion}

The evolution of knowledge concerning renovascular disease began in 1934 with the pioneering experimental studies of Goldblatt et al, ${ }^{1}$ that demonstrated in dogs the association between renal disease and hypertension. Through the placement of clips in renal arteries, these works provided new study models and a reproducible way of inducing experimental hypertension, and since then the production of stenosis in renal arteries have been performed in several animal species. With these studies two different models of experimental hypertension can be produced: (1) one stenosed renal artery with the opposite kidney intact - model two kidneys-one stenosis, and (2) one stenosed renal artery with the removal of the opposite kidney - model one kidney-one stenosis. With these two models the animals become equally hypertensive in spite of different physiopathology. In the model one kidney-one stenosis the plasmatic volume is expanded, with normal or suppressed renin secretion. ${ }^{7}$ In the model two kidneys-one stenosis the activity of plasmatic renin and the aldosterone secretion are increased, at expenses of the ischemic kidney. The clinical concept with relation to chronic renal isquemia in humans involved more recent events. Those began in 1988 with Jacobson, ${ }^{3}$ and passed initially by the definition and recognition of ischemic nephropathy as a clinical entity. The chronic renal ischemia in humans represents a potentially reversible cause of end stage renal disease, whose treatment involves dialysis or renal transplant. ${ }^{8}$ The renal revascularization with the primary objective of reverting both the renovascular disease and the renal function comprise a new concept within the medical practice. Morphologic studies of the structural lesions resulting from renal ischemia have not been related. This fact contributes to the lack of understanding of the
CHART 1 - Ultra-structural findings in proximal tubules.

Proximal tubular cells with undifferentiated appearance

- Cellular membrane with decrease/absence of the lateral basal invaginations (brush border).

- Organelles with undifferentiated appearance and reduced in number.

- Loss of the cellular polarization.

Tubulitis (mononuclear cells infiltrate)

- Tubular cells in contact with mononuclear cells presenting occasional degenerative alterations, like focal destruction of cellular membrane and rupture of organelles.

Proximal tubular cells with duplication of basal membrane.

Electron-dense deposits.

Increase of electron-dense deposits in cells of the juxtaglomerular apparatus.

Cellular debris in tubular lumen.

mechanism or the direct effects for which the ischemia produces lesion in the renal parenchyma. The present model was executed using the rat as the animal on study. According to Heptinstall, ${ }^{9}$ the ischemic kidney of the rat simulates the lesions observed in humans, even in details. In this manner, the rat kidney exposed to chronic ischemia develop diffuse tubular atrophy with cellular simplification, little interstitial fibrosis and good glomerular preservation. The unique histologic finding rare in humans and frequent in the rat is the interstitial inflammation (infiltrate). In our study the renal artery stenosis was produced through the placement of one atraumatic ligation with surgical thread of 5-0 nonabsorbable polipropilene suture around a cylindrical probe with $0,26 \mathrm{~mm}$ diameter, corresponding to the metallic portion of a $30 \mathrm{G}$ needle, as preconized by Truong et al. ${ }^{10}$ This stenosis model was also utilized by other authors with small variants, like Koletsky and RiveraVelez ${ }^{11}$ and Gobe et al. ${ }^{12}$ In some experiments were used metallic probes with larger diameter (cylinder with $26 \mathrm{G}$ ), and in others the variant consisted in the production of two ligatures distant $9 \mathrm{~mm}$ one of the other. In all of these situations the results were satisfactory, with stenosis close to $80-90 \%$ in the renal artery. In some works ${ }^{13}$ the authors utilized premolded metallic clips of silver 1000 , with internal distance among 0.20 to $0.25 \mathrm{~mm}$. The malleableness of this metal, together with the absence of inflammatory reaction for the presence of strange body, justified its choice by these authors. In our center, one reference to the use of the silver clip is in the study of Shiba et al, ${ }^{13}$ that related certain technical difficulty for the production of renovascular hypertension through clipping the abdominal aorta. The end of the experiment took place in the $49^{\text {th }}$ day (time 7 ), because at this period the ischemic kidneys became quite contracted and with fibrotic appearance, making impossible additional 
analysis. Other authors ${ }^{10,12}$ defined this limit of time in 60 days, because they didn't observe additional progression of lesions. The presence of gross scars on the renal surface was observed progressively from the $5^{\text {th }}$ week of the experiment (time 5). Geyskes et $\mathrm{al}^{14}$ reported in one clinical study the constant presence of these lesions in a group of patients $(n=17)$ with advanced renovascular disease treated with nephrectomy. At the final of our experiment (49 days) most of the kidneys presented with typical appearance of "ischemic contracted kidneys ", in a similar way observed by these authors in humans. ${ }^{14}$ The weight of the ischemic kidneys presented progressive reduction beginning from the $1^{\text {st }}$ week of the study. This finding reflects the loss of renal parenchyma according to global atrophy induced by ischemia. The presence of preserved renal glomeruli in the course of the experiment confirmed the reports of the literature. Truong et $\mathrm{al}^{10}$ and Gobe et al, ${ }^{12}$ using the model two kidneys-one stenosis examined the ischemic kidney in several intervals of time in a manner similar to our study. These authors observed the integrity of the glomeruli with the common finding of ischemic glomerular collapse (collapse of the glomerular walls with shrinkage and contraction of the capillary loops and reduced cellularity). In our study the presence of glomerular collapse was found in about $1 / 4$ of the analyzed glomeruli. Most studies indicate that the tubules are the greatest affected portion in chronic renal ischemia, with tubular atrophy being the finding more evident. ${ }^{10}$ The study of Cantin et $\mathrm{al}^{15}$ provides a complete picture of the effects of chronic ischemia, in which tubular atrophy developed rapidly and progressively in the external cortex. The juxtamedullar or internal cortex presented the same findings with the associated presence of focal necrosis of tubular cells. In our experiment the ischemic kidney presented several lesions like diffuse atrophy, loss of the board-in-brush and necrosis of tubular cells. A frequent report in the literature that was not observed in our study is the presence of tubulitis (mononuclear cells among tubular cells). ${ }^{16}$ The significance of tubulitis in humans deserves more explanation, not being exclusive of RVD, also occurring in other nephropathies, as diabetic nephropathy, lupus glomerulonephritis, IgA nephropathy and so on. ${ }^{2}$ The diffuse tubular atrophy was observed prematurely and in almost all animals, being the more frequent histologic finding. It was not observed the occurrence of a pick for these lesions, in a different way from the results of Truong et al, ${ }^{10}$ that conclude for the occurrence of pick for the tubular lesions in the $28^{\text {th }}$ day ( $4^{\text {th }}$ week). The interstitial alterations also prevailed in our study, with the inflammatory infiltrate in slight to moderate degrees (exclusively mononuclear with diffuse distribution) the more common finding. According to Truong et al, ${ }^{10}$ that related similar results, this inflammatory infiltrate would have uncertain meaning, being a part of a simple mechanism of cleaning and healing of damaged tissues, or constitute part of an progressive renal lesion. The presence of tubulitis, in this sense, could represent the occurrence of an autoimmune reaction as the mechanism of renal lesion. In the ultra-structural analysis the most prominent alterations were observed almost exclusively in the proximal tubules, with tubular cells adopting an undifferentiated appearance, with cellular membrane without lateral invaginations and board-in-brush, with sparse organelles and loss of cellular polarity. Again the literature ${ }^{17}$ mention the presence of tubulitis as a common ultra-structural finding, a fact not observed in our experiment. The presence of electron-dense deposits was observed in later periods in the experiment, and is probably related to possible immune mechanisms for the renal lesions. This fact is confirmed in other works by the presence of immune complexes in immunofluorescence studies. ${ }^{10}$ The presence of autophagolysosomes is related to cellular necrosis, being constituted in the main mechanism for degradation of proteins and cellular organelles.

\section{Conclusions}

- The developed model was satisfactory for the analysis of morphologic, histological and ultra-structural alterations in ischemic kidneys of rats.

- The predominant histological alterations in the ischemic kidney consisted in tubular atrophy and interstitial infiltrate.

- The ultra-structural analysis demonstrated glomerular integrity and the typical findings of chronic ischemia at the proximal tubules.

\section{References}

1. Goldblatt H, Lynch J, Hanzal RF, Summerville WW. Studies on experimental hypertension. I. The production of persistent elevation of systolic blood pressure by means of renal ischemia. J Exp Med. 1934;59:347-79.

2. Textor SC. Renovascular hypertension and ischemic nephropathy. In: Brenner \& Rector. The kidney. 7ed. New York: Elsevier; 2004. p. 2065-104.

3. Jacobson HR. Nephology Forum: ischemic renal disease: an overlooked clinical entity? Kidney Int. 1988;34:729-43.

4. Mailloux LU, Bellucci AG, Mossey RT, Napolitano B, Moore T, Wilkes BM, Bluestone PA. Predictors of survival in patients undergoing dialysis. Am J Med. 1988;84:855-62.

5. Hricak H, Lieto RP. Sonographic determination of renal volume. Radiology. 1983;148:311-2.

6. Pirani CL, Croker BP. Handling and processing of renal biopsy and nephrectomy specimens. In: Tisher CC, Brenner BM. Renal pathology: with clinical and functional correlations. 2ed. Philadelphia: Lippincott Company; 1994. p. 1683-93.

7. Liard JF, Cowley AW, McCaa RE, McCaa CS, Guyton AC. Renin, aldosterone, body fluid volumes, and the baroreceptor reflex in the development and reversal of Goldblatt hypertension in concious dogs. Circ Res. 1974;34:549-60. 
8. Kimmel PL. Management of the patient with chronic renal disease. In: Greenberg A. Primer on kidney diseases. 1ed. San Diego: Academic Press; 1994. p. 281-7.

9. Heptinstall RH, Salyer DC, Salyer WR. The effects of chemical ablation of the renal papilla on blood pressure of rats with and without silver-clip hypertension. Am J Pathol. 1975;78:297-308.

10. Truong LD, Farhood A, Tasby J, Gillum D. Experimental chronic renal ischemia: Morphologic and immunologic studies. Kidney Int. 1992;41:1676-89.

11. Koletsky S, Rivera-Velez JM. Factors determining the success oo failure of nephrectomy in experimental renal hypertension. J Lab Clin Med. 1970;76(1):54-65.

12. Gobe GC, Axelsen RA, Searle JW. Cellular events in experimental unilateral ischemic renal atrophy and in regeneration after contralateral nephrectomy. Lab Invest.1990;63:770-9.

13. Shiba AS, Macedo Neto A, Ruschel AC. Modelos de hipertensão renovascular em ratos. In: FAMED/ UFRGS ATM 95/1. 1ed. Porto Alegre: Artes Médicas;1995. p. 33-8.
14. Geyskes GG, Oei HY, Klinge J. Renovascular hypertension: the small kidney updated. Q J Med. 1988;66(251):203-17.

15. Cantin M, Solymoss B, Benchimol S. Metaplastic and mitotic activity of the ischemic (endocrine) kidney in experimental renal hypertension. Am J Pathol.1979; 96:545-66.

16. Ooi BS, Jao W, First MR. Acute interstitial nephritis. Am J Med. 1975;59:614-29.

17. Ivanyi B, Marcussen N, Olsen. Tubulitis in primary vascular and glomerular renal disease. Pathol Res Pract. 1995;191(12):1245-57.

\section{Acknowledgments}

The authors would like to thank Evandro Sobroza de Melo, MD for kindly providing histological analysis, Carlos Fernando de Mello, MD, PhD for his research laboratory and Severo Barros, MD for kindly providing ultra-structural analysis.

\section{Correspondence:}

Clóvis Luís Konopka

Rua Duque de Caxias, 1668/803

97015-190 - Santa Maria - RS - Brazil

Phone/Fax:(55 55)3222-7552

e-mail:konopka@terra.com.br
Conflict of interest: none Financial source: CAPES/MEC

Received: August 15, 2006

Review: September 12, 2006

Accepted: October 10, 2006

\section{How to cite this article:}

Konopka CL, Jurach A, Wender OCB. Experimental model for the study of chronic renal ischemia in rats: morphologic, histological and ultra-structural analysis. Acta Cir Bras. [serial on the Internet] 2007 Jan-Feb;22(1). Available from URL: http://www.scielo.br/acb. 